UDC: 159.9

DOI: https://doi.org/10.24195/2414-4665-2017-7-23

\author{
Mariia Kazanzhy, \\ Doctor of Psychological Sciences, professor, \\ Department of General and Differential Psychology, \\ South Ukrainian National Pedagogical University named after K. D. Ushynsky, \\ 26, Staroportofrankivska Str., Odesa, Ukraine
}

\title{
THE IMPORTANCE OF FACILITATION IN SUCCESSFUL ADAPTATION
}

This paper presents the data concerning the connectedness of the facilitative potential components, its manifestation in different fields of vital activity, basic senses of helping behaviour and socio-psychological adaptability. Based on the results of multiple regressive analysis, there has been established the importance of all facilitation aspects in order to predict personality adaptability. It has been proved that persons with developed facilitation have a higher degree of adaptability (on the sample of socionomic professions). The study of the peculiarities of adaptation directly in a complex life situation which is the process of accommodation to a foreign environment that can be combined with the beginning of family relations and is a rather tense and difficult period in subjects' lives has shown the importance of the facilitative ability in the success of its course. The obtained data provide valuable information on possible ways to increase the individual adaptivity through the development, formation of their facilitative potential, as well as the facilitative qualities of the social environment.

Keywords: facilitative ability, facilitative potential, fields of facilitation, sense motivation of help, adaptation, socio-psychological adaptability.

\section{Introduction}

The relevance of the given work is caused by the needs of the modern world. On the one hand, people are in constant movement, development that is reflected in social mobility which requires timely and successful adaptation. On the other hand, this mobility is often due to rather significant negative reasons (military conflicts, persecutions for political reasons, etc.) that is related with certain difficulties in adaptation. Proceeding from the high social significance of the indicated problem, there is an attempt to study the factors that contribute to a more successful socio-psychological adaptation of the individual, among which the facilitative ability as a personal quality promoting human development is the focus of our attention.

Accordingly, the aim of this paper was to study the facilitative potential, its manifestation in different fields of vital activity as a factor of successful adaptability.

It is worth noting that most often facilitation in the context of the adaptation issues is considered as a method, technique, adaptation mechanism. Thus, sociopsychological adaptation was carried out through facilitation (V. Bertenev, 1997 [2]), facilitation of personal adaptation was accomplished through creative self-expression (A. Filozop, 2005 [13]), disadaptation was overcome by the means of facilitation (S. Olifira, 2012 [11]), etc. We share C. Rogers' [14] views on the definition of facilitation, emphasizing the awareness and purposefulness of the process of the facilitating influence, considering that the facilitative ability is a psychological quality of a person which is a manifestation of his/her facilitative potential.

It should be mentioned that the facilitative potential is a unity of two integral constituents: actualizing and resourceful. Correspondingly, the facilitative ability is a psychological quality of a person which is a manifestation of the facilitative potential. This quality differs from a personal trait or characteristic by less stability as it is actualized in the period of conscious purposeful facilitating activity. It can become "contracted", latent - to turn into a potential in those periods when there is no request for help in the development of another person. This also relates to the inhibiting ability, which we consider the inverse side of the facilitative ability but with the opposite direction. In fact, the facilitative and inhibiting abilities are one and the same phenomenon with the opposite sign, both of them can be in a potential state; the inhibiting ability is also a temporarily actualized potency. Consequently, both the facilitative and inhibiting abilities can be in the form of a potential and quality. Although we are talking about the sides of one and the same phenomenon, the essence of which is resolved into the influence of one person to another, in the study we focus on one facet of the manifestation - the facilitative ability as it is the most in-demand in practical terms.

The study was conducted on the basis of South Ukrainian National Pedagogical University named after K.D. Ushynsky. The sample included 400 students aged 18 to 26 . The sample is relatively narrowly focused in the terms of professional affiliation of subjects - representatives of "person-to-person" type, i.e. future teachers. Such narrowness is determined by the need for a deeper study of the facilitative ability features, as most researchers, such as C. Rogers [14], O. Kondrashykhina [9], M. Aminov [1], M. Molokanov [1], I. Zhyzhyna [6], R. Dimukhametov [5], L. Timonina [12], O. Vrubliovska [3], N. Nosova [10] and others indicate that those who choose a profession associated with helping a person - in devel- 
opment, gaining knowledge, personal growth, etc. - have a significant degree of the facilitative ability.

\section{Research Methods}

The implementation of the study took place in several directions. The first direction was aimed at the empirical study of the connectedness between adaptation and facilitation with the help of correlation analysis, and the search of the variables making the greatest contribution to the intensity of adaptivity by the means of multiple regression analysis. The main methods to study the facilitative ability and adaptivity were: "Test-questionnaire of the personal facilitative potential", which measures emotional, cognitive, strong-willed, requirementalmotivational, behavioral and sense-valuable components that in some combination represent the actualizing and resourceful constituents of the personal facilitative potential; "The research method of sense motivation of help", determining the intensity of certain indices: facilitation, inhibition, centration, decentration, negativity, existentiality, self-knowledge, communicative ability, compliance with social norms; "Diagnostics of individual differences of the facilitative ability of a person according to the spheres of manifestation", giving information about manifestations of the facilitative ability in five areas (education and upbringing, family, friendly, professional, general human relations) by solving specific life situations; "The scale of socio-psychological adaptability” (C. Rogers, R. Dimond, adapted by A.K. Osnitskiy) [4], that allows to diagnose adaptability and disadaptability, acceptance and rejection of themselves, acceptance and rejection of others, emotional comfort, emotional discomfort, internal and external control, domination, submissiveness, escapism. There was also used a complex of methods to study psychological qualities of the personality associated with the adaptivity - the obtained results are not fully presented, there are only the data concerning the facilitative ability and adaptivity.

\section{Discussion}

The indicators of the personal facilitative potential demonstrate close correlation relations with the adaptivity parameters. This result corresponds with the hypothesis of our study, although this aspect has not been studied before. The established fact is very important for the representatives of socionomic professions. In everyday life at the expense of inhibition (counteraction to development) people adapt very well, absolutely not focusing on the interests of another person, achieving only their own purposes. Belonging to the so-called "helping" profession imposes certain restrictions on the mechanisms by which a person adapts in the society, thus inhibition is a mechanism which is socially unacceptable for a teacher, however, it may be applied in the hidden, implicit form [7].

It should be noted that all indicators of the facilitative potential positively correlate with the essential parameters of the adaptability of a person, and negatively with the parameters of those psychological characteristics, manifestation of which disadapt a man in the society. The facilitative ability as a basic sense of help is not connected with the adaptivity but correlates with such a characteristic of the adaptivity as acceptance of others.

Inhibition as a sense of helping another person is connected with the reduction of the socio-psychological adaptivity and acceptance of others. Consequently, the centration on helping another person with his/her problems; the lack of inhibiting senses in helping actions; no inclination to solve their own problems in helping actions directed at another person favour adaptability [7].

Based on the multiple regression analysis results, the importance of predicting the adaptability of the facilitative characterstics intensity has been established. Although taking into account the existing data about famous facilitators, it is worth mentioning that there were periods of the disadaptability in their lives. "Now I understand that I was special, a loner with a remote opportunity to find my place in the human world. Practically I did not know how to behave in the society of people," C. Rogers wrote about one of such stages of his life [14, p. 4]. It doesn't mean that they are disadapted (it's not necessary at all), but it means that facilitators can use this experience to help another person, because after the period of disadaptation, having comprehended it, they receive a huge resource serving as a source of helping others.

The second direction suggested studying the features of adaptation in a complex life situation, which is the process of accomodation to a foreign environment that can be combined with the beginning of family relations and is a rather tense and difficult period in subjects' lives.

Within this direction of our empirical research we involved a sample which can be conditionally divided into several groups. The first group included local students. The second one - students from the Republic of Turkey, Turkmenistan, Uzbekistan and the People's Republic of China, studying at the university and adapting to completely different living conditions. A separate (third) group consisted of foreign students currently studying or graduated from higher education institutions, most of whom married the citizens of Ukraine (some families had children). We mean the citizens of Ukraine by the term "local" students.

Observation and conversation were chosen as the main methods. Testing was also used to study the respondents' facilitative ability.

The clash of the differences in language, religion, culture, etc., leads to difficulties that subjects solve in different ways and not always successfully. First, let's speak about the group of participants adapting to a foreign environment. Our observations have shown that their behavior is quite isolated, they adhere to their traditions (that is why, for example, they do not attend classes during religious holidays), always try to stick together with "their own" people, communicate primarily in their native language, etc. This type of behavior is often not very productive, because only formal communication with local students leads to poor mastering of the Russian language.

However, even in this group, there are foreign stu- 
dents who actively communicate with local students, so they speak Russian well, that gives them wide opportunities not only for communication, but also for training, which is confirmed by their high enough marks. It is worth noting that the initial level of language knowledge among all foreigners was approximately the same.

The additional study of this fact with the participation of local students has shown that not only a sufficient number of foreigners in the student group (slightly less than half), but a special facilitating atmosphere reigning in it played an important role in this process.

Applying "Test-questionnaire of the personal facilitative potential" (M.I.Kazanzhy) [8], the personal facilitative potential parameters of the members of this group were measured (all the indicators of most students were at a high level). The effective adaptation and successful studying of foreign students who are part of this training group can be explained by the facilitative ability intensity of its memebers (the ability to support, promote, provoke, etc.). According to the results of our observation, in the group they feel very comfortable, show high activity in training and public affairs, their compatriots from other groups express a desire to transfer to this training group.

The obtained result is quite significant, as it reveals new opportunities for helping young people in a difficult life situation, which is the process of accomodation to a new cultural environment. Being "close" to the people with the developed facilitative potential can successfully replace the psychological accompaniment of foreign students. The main factor of the social environment facilitative ability is the presence of the facilitating personalities in the group. The given data can be taken into account when completing the training groups: local students with a high level of the facilitative potential can constitute a considerable part of the group and thus form a facilitating environment for foreign students (a powerful impetus for their personal development is created).

After all, it is very important to have not only kind, friendly and sympathetic people near you, but those who are genuinely interested in personal development of others, who can influence others in a facilitating way. Undoubtedly, other personal qualities - the developed empathy, tolerance, etc. - make a solid contribution, too. Many studies have shown that these psychological characteristics are the eternal "satellites" of the facilitative ability (C. Rogers, I.V. Zhyzhyna, O.A.Kondrashykhyna and others), therefore we are not going to describe these data now.

Generalizing the results of the study of multicultural student families (the third, relatively small, group of subjects), it is possible to see another facet of the personal facilitative potential manifestation. Husbands with the developed facilitative ability demonstrate more tolerant, balanced and understanding behaviour. They do not hinder, but on the contrary - encourage the wife's desire to do what she likes, are proud of her achievements, do not impose her ideas on the acceptable social behavior of a woman. Conversations with such couples showed that mutual love is closely intertwined with the striving for developing all the best in the lifemate (here should be mentioned E. Fromm's understanding of love).

As a result, everyone can make the most general conclusions. The developed facilitative potential of the surrounding people makes it possible to adapt to the environment that differs from the usual one in many aspects (religion, culture, language, etc.) successfully, with minimal mental costs. In the life of a polyethnic young family, the facilitative potential of the spouses promotes the harmonious development of relations, the formation of traditions taking into account the specific features of both cultures.

We do not claim that only the facilitative qualities of the surrounding people are a key factor in overcoming difficult life situations, but their great role is beyond any doubt. Moreover, while being present in the group, most members of which have the developed facilitative qualities, one can speak about a facilitating environment, the influence of which is sometimes even more powerful, since it is not a simple sum of the facilitative capabilities of individual group members, but accumulates the complex group facilitative energy. The data obtained can be applied to any social groups of young people who are in similar difficult life circumstances (emigrants working under contracts, etc.)

\section{Conclusion}

As a result of the conducted research it is possible to conclude the following:

1. The socio-psychological adaptatability is positively connected with the manifestation of the facilitative ability in all fields of vital activity. Accordingly, the facilitative ability can contribute to the adaptability of a person, which does not exclude the possibility of being adapted not only for a non-facilitative, but even for the inhibited person. The mechanisms for adapting such a person are completely different. A human will not become automatically adapted only by making the facilitating impacts, but facilitation, like any activity, promotes adaptation and can prolong the adaptability period.

In our opinion, the connection between the adaptability and the facilitative ability is the most frequent case, which is confirmed by the methods of mathematical statistics. However, examples from the world culture and science clearly demonstrate the intensity of facilitation in creative, sometimes completely disadapted in society, people.

2. The developed facilitative potential of the surrounding people contributes to the successful adaptation to the unusual social environment. This generalization concerns all fields of vital activity. In particular, in the family life, the facilitative potential of the spouses promotes the harmonious development of relations, the formation of traditions taking into account the specific features of both cultures. In the field of training and education, it leads to a higher level of academic success, comfortable learning process, the communicative ability development, etc. 
3. Theoretical data and statistical studies are confirmed by less formalized, individually directed methods, which is an indisputable basis for further scientific research in this direction.

4. This work does not exhaust the list of issues requiring a more thorough study in the relationship "the facilitative ability - socio-psychological adaptability". The facts obtained in the study are appropriate only for people whose professional duty is to help others, which has an effect on all their personal characteristics.

\section{REFERENCES}

1. Aminov, N. A., Molokanov, M. V. (1992). Sotsialno-psikhologicheskiye predposylki spetsialnykh sposobnostey shkolnykh psikhologov [Sociopsychological preconditions for school psychologists' special abilities]. Voprosy psikhologii - Psychology Issues, 1, 74-83 [in Russian].

2. Bertenev, V.A. (1997). Pedagogicheskiye usloviya fasilitatsii sotsialnoy adaptatsii starsheklassnikov sredstvami fizicheskoy kultury [Pedagogical conditions of facilitation of senior pupils' social adaptation by means of physical culture]. Candidate's thesis. Yaroslavl [in Russian].

3. Vrublyovskaya, E.G. (2001). Razvitiye sposobnos$t i$ pedagogov $k$ fasilitiruyushchemu obshcheniyu: uchebnoye posobiye [Development of teachers' abilities for facilitating communication: textbook]. Khabarovsk [in Russian].

4. Nikiforova, G.S. (Ed.) (2007). Diagnostika zdorovya. Psikhologicheskiy praktikum [Diagnostics of health. Psychological workshop]. Saint Petersburg: Rech [in Russian].

5. Dimukhametov, R.S. (2006). Fasilitatsiya v sisteme povysheniya kvalifikatsii pedagogov [Facilitation in the system of teachers' professional development]. Doctor's thesis. Magnitogorsk [in Russian].

6. Zhizhina, I.V. (2000). Psikhologicheskiye osobennosti razvitiya fasilitatsii pedagoga [Psychological features of teacher's facilitation development]. Candidate's thesis. Yekaterinburg [in Russian].

7. Kazanzhy, M.I. (2013). Rezultaty i perspektivy issledovaniya fenomena fasilyativnosti $\mathrm{v}$ kontekste problemy adaptirovannosti lichnosti [The phenomenon of the facilitative ability research in the context of personal adaptability problems: results and perspectives]. Vestnik KazNU. Seriya psikhologii i sotsiologii - KazNU Bulletin: Psychology and Sociology, 3 (46), 38-45 [in Russian].

8. Kazanzhy, M.I. (2010). Fasilyativnyi potentsial sotsialnoy sredy kak odin iz faktorov uspeshnoy adaptatsii molodezhi $\mathrm{v}$ polikulturnom zhiznennom prostranstve

\section{ЛІТЕРАТУРА}

1. Аминов Н. А., Молоканов М. В. Социальнопсихологические предпосылки специальных способностей школьных психологов / Н. А. Аминов, М. В. Молоканов // Вопросы психологии. - 1992. №1. - C. 74-83.
Studying concrete techniques and methods of the facilitative ability development in order to increase the adaptability of a person is one of the most interesting and relevant prospects for further research. The influence of the personal facilitative potential, social environment as a powerful factor in enhancing the effectiveness of adaptation is undoubtedly a subject of the detailed study not only in terms of the facilitative ability genesis.

[Facilative potential of the social environment as one of the factors of successful adaptation of youth in the multicultural living space]. Molodezh $v$ sovremennom obshchestve: problemy i resheniya - Young people in modern society: problems and solutions. Proceedings of the International Scientific and Practical Conference (pp. 6769). Pskov: PGPU im. S. M. Kirova [in Russian].

9. Kondrashyhina, O.O. (2004). Formuvannya zdatnosti do fasylitatsiynykh vplyviv u maybutnikh praktychnykh psykholohiv [Formation of the ability to facilitating influences in future practical psychologists]. Candidate's thesis. Kyiv [in Ukrainian].

10. Nosova, N.V. (2007). Osobystisni determinanty humanizatsiyi vzayemyn u pedahohichnomu protsesi [Personality determinants of relationship humanization in the pedagogical process]. Extended abstract of candidate's thesis. Kyiv [in Ukrainian].

11. Olifira, S.O. (2012). Teoretychni problemy podolannya adaptatsiynoyi kryzy zasobamy fasylitatsiynoho vplyvu [Theoretical problems of overcoming adaptation crisis by means of facilitation influence]. Visnyk Chernihivskoho natsionalnoho pedahohichnoho universytetu. Psykholohichni nauky - Bulletin of Chernihiv National Pedagogical University. Psychological Sciences, 103 (2) [in Ukrainian].

12. Timonina, L.I. (2002). Sotsialnopsykhologicheskaya fasilitatsiya uchebnoy deyatelnosti neuspevayushchikh podrostkov [Social-psychological facilitation of unsuccessful teenagers' educational activity]. Candidate's thesis. Kostroma [in Russian].

13. Filozop, A.A. (2005). Fasilitatsiya lichnostnoy adaptirovannosti $\mathrm{v}$ period pozdney vzroslosti sredstvami tvorcheskogo samovyrazheniya [Facilitation of the personal adaptability in the period of late adulthood by means of creative self-expression]. Candidate's thesis. Voronezh [in Russian].

14. Rogers, C. R. (1973). My philosophy of interpersonal relationships and how it grew. Journal of Humanistic Psychology, 13, 3-16 [in English].

2. Бертенев В. А. Педагогические условия фасилитации социальной адаптации старшеклассников средствами физической культуры: дис. ... канд. пед. наук : 13.00.01 / Валерий Алексеевич Бертенев. - Ярославль, 1997. - 143 с. 
3. Врублевская Е. Г. Развитие способности педагогов к фасилитирующему общению: [учебное пособие] / Е. Г. Врублевская. - Хабаровск, Изд-во «Колорит», 2001. - 182 с.

4. Диагностика здоровья. Психологический практикум / [Под ред. проф. Г. С. Никифорова]. - СПб.: Речь, 2007. - 950 с.

5. Димухаметов Р. С. Фасилитация в системе повышения квалификации педагогов: дис. на соиск. учен. степ. докт. пед. наук : 13.00.08 / Димухаметов Рыфкат Салихович. - Магнитогорск, 2006. - 398 с.

6. Жижина И. В. Психологические особенности развития фасилитации педагога: дис. ... канд. психол. наук : 19.00.07 / Жижина Инна Владимировна. - Екатеринбург, 2000. - 153 с.

7. Казанжи М.И. Результаты и перспективы исследования феномена фасилятивности в контексте проблемы адаптированности личности / М. И. Казанжи. - Вестник КазНУ. Серия психологии и социологии. - № 3 (46). - 2013. - С. 38-45.

8. Казанжи М.И. Фасилятивный потенциал социальной среды как один из факторов успешной адаптации молодежи в поликультурном жизненном пространстве // Молодежь в современном обществе: проблемы и решения: Междунар. научно-практ. конференция, РФ, Псков, 30 сентября - 2 октября 2010 г. Псков: ПГПУ им. С. М. Кирова, 2010. - С. 67-69.

9. Кондрашихіна О. О. Формування здатності до фасилітаційних впливів у майбутніх практичних пси- хологів: дис. ... канд. психол. наук: 19.00.07 / Оксана Олександрівна Кондрашихіна. - К., 2004. - 239 с.

10. Носова Н. В. Особистісні детермінанти гуманізації взаємин у педагогічному процесі: атореф. дис. на здобуття наук. ступеня канд. психол. наук: спец. 19.00.07 «Педагогічна та вікова психологія» / Н. В. Носова. - К., 2007. - 22 с.

11. Оліфіра С. О. Теоретичні проблеми подолання адаптаційної кризи засобами фасилітаційного впливу / С. О. Оліфіра // [Електронний ресурс]: Вісник Чернігівського національного педагогічного університету. - 2012. - Випуск 103, Том 2. - Психологічні науки. - Режим доступу: www.archive.nbuv.gov.ua/portal/Soc_Gum/Vchpdu/psy/2 012_103_2/Olifira.pdf

12. Тимонина Л. И. Социально-психологическая фасилитация учебной деятельности неуспевающих подростков : дис. ... кандидата педагог. наук : 13.00.02 / Тимонина Любовь Ильинична. - Кострома, 2002. $-212 \mathrm{c}$

13. Филозоп А.А. Фасилитация личностной адаптированности в период поздней взрослости средствами творческого самовыражения: дис... канд. психол. наук : 19.00.13 / Филозоп Александр Анатольевич. Воронеж, 2005. - 232 c.

14. Rogers C. R. My philosophy of interpersonal relationships and how it grew / C. R. Rogers. - Journal of Humanistic Psychology. - 1973. - № 13 - P. 3-16.

\section{Марія Йосипівна Казанжи, доктор психологічних наук, професор кафедри загальної та диференціальної психології, Південноукраінскій національний педагогічний університет імені К. Д. Уиинського, вул. Фонтанська дорога, 4, м. Одеса, Україна}

\section{ЗНАЧЕННЯ ФАСИЛІТАЦІЇ В УСПІШНІЙ АДАПТАЦІЇ}

У статті наведено відомості щодо зв'язаності компонентів фасилятивного потенціалу особистості, його проявів у різних сферах життєдіяльності, а також основних смислів допомагаючої поведінки із соціальнопсихологічною адаптованістю. За результатами множинного регресійного аналізу встановлено значимість усіх аспектів фасилятивності для прогнозування адаптованості особистості. Доведено більш високу адаптивність в осіб з вираженою фасилятивностю (на прикладі соціономічних професій). Дослідження особливостей адаптації безпосередньо в складній життєвій ситуації, якою є процес пристосування до іншомовного середовища, що може поєднуватися 3 початком сімейних відносин і є для випробовуваних досить напруженим і важким періодом у житті, показало значимість фасилятивності в успішності її протікання. Отримані дані несуть цінну інформацію щодо можливих шляхів підвищення адаптивності особистості шляхом розвитку, формування їі фасилятивного потенціалу, а також фасилятивних якостей соціального оточення.

Ключові слова: фасилятивність, фасилятивний потенціал, сфери фасилітації, смислова мотивація допомоги, адаптація, соціально-психологічна адаптованість. 